\title{
Sense of Place and Placelessness of Urban Open Spaces in Dar es Salaam
}

\author{
Edson E Sanga ${ }^{1} \&$ Daniel A Mbisso ${ }^{1}$ \\ ${ }^{1}$ Department of Architecture, Ardhi University, Tanzania \\ Correspondence: Daniel Mbisso, Department of Architecture, Ardhi University, P.O. Box 35176, Dar es Salaam, \\ Tanzania. Tel: 255-7-8495-4735. E-mail: mbissod@gmail.com; mbisso@aru.ac.tz
}

Received: April 19, 2020

doi:10.5539/jsd.v13n4p191
Accepted: May 25, $2020 \quad$ Online Published: July 29, 2020

URL: https://doi.org/10.5539/jsd.v13n4p191

\begin{abstract}
Provision of urban open spaces, such as parks and squares has been manifested during planning and designing of cities with the goal of enhancing ecological, social and economic benefits. Socially, it is argued that urban open spaces offer urban residents solace and recreational platforms where residents can interact and perform active and passive recreational activities. Through observations and interviews conducted in two urban squares in Dar es Salaam, it has been revealed that the spaces do not produce a sense of place to its users due to low frequency of visitors and unintended uses. This paper concludes that in order to enhance sense of place, the provision of urban open spaces should address the socio-cultural everyday experiences and desires of the target population.
\end{abstract}

Keywords: urban open spaces, intended use, actual use, sense of place, placelessness

\section{Introduction}

\subsection{Research Background and Problem Statement}

The provision and improvement of urban open spaces in cities are significantly important to accommodate the proliferation of urban dwellers in recent years. Statistics reveal that urban population across the globe has increased where by in 2016, urban settlements are estimated to occupy 54.5 of the world's population (UN, 2016). The fast increase in population and the expansion of cities bring challenges on social economic and environmental stability of cities' growth (Gozalo et al., 2018). Urban open spaces are overwhelmed for that matter and, therefore, planners and designers are concerned in the provision and improvement of the spaces.

UN-Habitat (2015) has been in the forefront on enhancing the provision and improvement of public spaces [Urban open spaces] for citizens. "Cities that have strong notion of the public, demonstrate a commitment to an improved quality of life of their citizen by providing adequate street space, green area, parks, recreational facilities and other public spaces" (UN-Habitat 2015:4).

Place making has become a central means among others, mainly a top-down approach used by professionals to make cities and spaces livable (Bishop and Marshall, 2017). Emanating in 1960 by writers such as Jane Jacobs and William $\mathrm{H}$. Whyte, the concept of place making was centered on design of cities that cater for people (Behera, 2017). Since then the concept has gained momentum across various places and challenges traditional modes or top-down-processes of urban design and planning (Bishop and Marshall, 2017). In the current discourses, the approach has been cumulatively gaining importance among professionals like landscape architects, architects and urban planners to describe processes of creating city spaces that attract people because they are enjoyable and appealing (Paris, 2017).The approach appreciates socio-spatial performance of an end-user as the most valuable perspective on how spaces should function, emphasizing that planning decisions by specialists should be made with the participation of the end-user (Thomas, 2016).

Although the provision of urban open spaces and its strategies seem to be significant in making spaces better places, the situation of urban open spaces in Dar es salaam is puzzling. Urban open spaces have been produced through the top-down mode (professional ideologies) for the intention of recreational use. However, the actual uses seem to be different from the intended uses. In this way, a different sense of place is revealed. This paper, therefore, was set to explore and discuss these disparities on the provision and use of urban open spaces. 


\subsection{Social Perspectives on Urban Open Spaces in Cities}

Urban open spaces including parks, gardens, squares, greenways and greenbelts have been provided to cities significantly for integration between human, environment and biodiversity (Li et.al, 2005 in (Adinolfi et al., 2014)). They play a great role in offering ecological, economic and social benefits to surrounding urbanites (Schindler et al., 2018). The human dimension is revealed when the spaces offer platform for solace and recreation where residents can interact and perform active and passive recreational activities (Dadvand et al., 2016, Jennings et al., 2016, Kabisch and Haase, 2014). Needs such as comfort, relaxation, enjoyment and social stimulation are satisfied through recreational activities and, therefore, signifying the importance of urban open spaces in cities (Salama and Azzali, 2015). This is possible by allowing access of people to the spaces (Teimouri et al., 2017, Fan et al., 2017). It is believed that as people access urban open spaces they attain various aesthetic enjoyments rendered through diverse sense of colour, shapes, texture and sound, which are provided by the spaces according to varied seasons, weather or time (Zhou and Parves Rana, 2012). It is through these qualities urban open spaces become essential for the promotion of people's health, happiness and well-being (Musa, Yacob, Abdullah, \& Ishak, 2017; San Juan, Subiza-Pérez, \& Vozmediano, 2017).

Despite the efforts of reconsidering urban open spaces as inevitable spaces to cities, arguably the efforts are not enough until such spaces are made to meet values connected to sense of place.

Low and Altman assert that 'urban open spaces, which meet attitudes of people become significantly important and contribute positively in creating sense of place and belonging to urban residents'(Low and Altman 1992) cited in (Johnson and Glover, 2013).

\subsection{Conceptualising Sense of Place and Placelessness}

Discourse of sense of place have flourished from classical conceptualization of a place depicting the relationship of people and the domain of environmental experiences (Norberg-Schulz, 1980, Tuan, 1990, Jackson, 1994). Arguably, relationship between people and place involves both physicality of a place as well as social interactions that occur within it (McCunn and Gifford, 2014). People draw meanings to places based on biophysical and aesthetical attributes (Chapin and Knapp, 2015), as well as social interactions (Kyle and Chick, 2007). Relph (1976) argued that 'spaces are changed into places when filled with physical environment, the observable human activities and the symbolic meanings. The first two components are easily observable by an outsider while the third requires views from those who belong to the spaces (ibid in (Waller et al., 2017).

Physical environment for urban open spaces contributes to sense of place when possessing physical qualities such as location, accessibility, linkages, size, shape and landscape features, which may include trees and water features (Whyte, 1980, Shaftoe, 2008, PPS, 2015a). These features are essential to attract people to urban open spaces. Furthermore, observable human activities are defined from behavior of use of urban open spaces; including time spent, type of activities, frequency of use as well as type of users (Burrows et al., 2018). Symbolic meaning of urban open spaces are drawn from perception of the way people value urban open spaces with regard to safety, attractiveness, comfort, relaxation, passive engagement, active engagement, discovery and fun (Carmona, 2010, Francis, 2003).

In addition, concepts like rootedness, belongingness, insideness, attachment, affiliation, appropriation, commitment, investment, dependency and identity are being used interchangeably to elaborate people-place relationship (Giuliani, 2003, Manzo and Devine-Wright, 2013). Consequently, Jorgensen and Stedman (2001) underscore three psychological attitudes to systematically understand a sense of place; affective (emotional), cognitive (meanings and values) and conative (behavioral inclination) (Jorgensen and Stedman, 2001). The aforementioned attitudes manifest feeling of specialness for a physical setting (McCunn and Gifford, 2017).

Sense of place can not only be appreciated based on positive values places have but also can be sensed negatively. According to Tan et al. (2018) 'people tend to appreciate place by the expression of both negative and positive feelings' (Tan et al., 2018), which are expressed through experiences such as feeling stimulated, exited, joyous, amused, sadness, longing and so forth (Steele, 1981). The negative experience of place is expressed when a place experience low possession of public life and reflects that the spatial and temporal environment is not significant source of meaning to people-hence placelessness is revealed (Misra and Stokols, 2012). The inactive use, unlovely, homogeneous and desertedness of a place (Freestone and Liu, 2016) indicate the lack of activeness of a place, the placelessness. Relph contends that "the casual eradication of distinctive places and the making of standardized landscapes results from insensitivity to the significance of a place" (Relph 1976 Preface) cited in (Low, 2017). Relph's assertion connotes that continuing to produce places with respect to quantitative qualities underplays the subtle meaning of human experience. Webber (1974) coined the concept of none-place synonymously with placelessness; by criticizing designers of spaces from engineering and architectural conception as a result of in- 
appropriation to intended users (Webber, 1974). Arguably, placelessness occurs when three components namely place-physical setting, activities and meaning are interrupted (Relph, 1976, Gkoutis, 2014, Bleam, 2018). The preceding discussion of sense of place and placelessness guides to understand the situation of urban open spaces in the context of Dar es salaam.

\section{Study Context and Method}

The city of Dar es Salaam is one of the fastest growing cities in Sub Sahara Africa, with a population of 4.4 million (URT, 2013) growing at 5.8 percent per annum during the last decade (Kiunsi, 2013). It is predicted that the population will grow at the even faster rate in the next decade, making the future city to become megacity by 2034 (UN-Habitat, 2014).

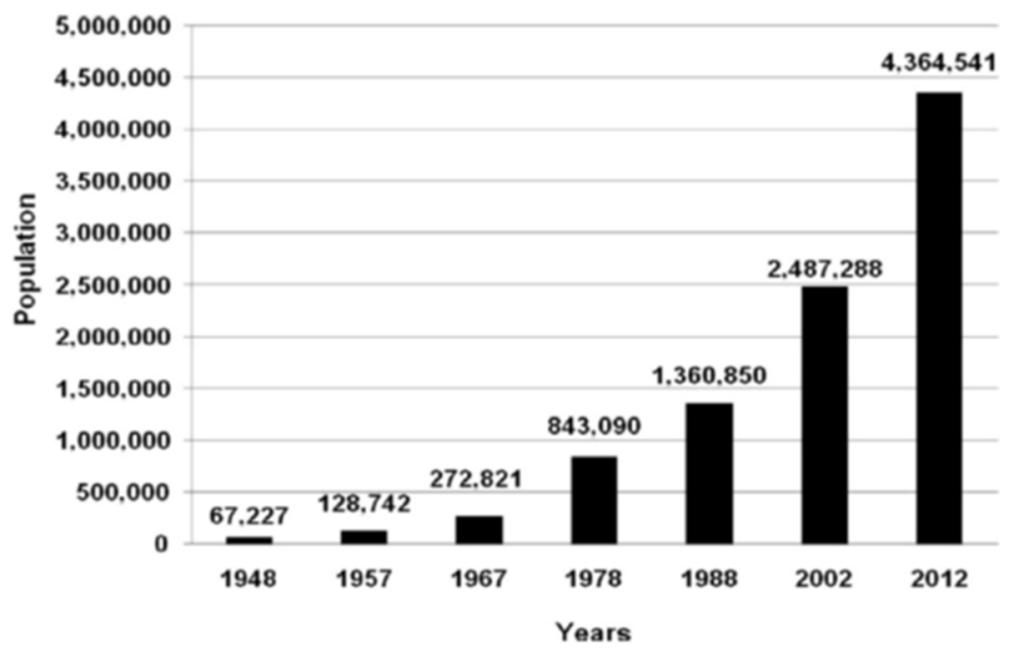

Figure 1. Population of Dar es salaam

Source: NBS (2013)

The city expands from its center in the harbor outwards along its major arterial roads, forming a radial development pattern whereby the fastest growth to the periphery grows partly planned and partly unplanned (Andreasen, 2013).The unplanned parts are commonly known as informal settlements. Up to the year 2012, large part of the city was occupied by informal settlements hosting 80 percent of its population residing in the areas (URT-DMP, 2012, Andreasen, 2013). The planned part of the city comprises clearly defined and dermacated green open spaces unlike the unplanned part, which is characterized mainly by compactness of buildings that are organised in an irregular spatial pattern (Augustijn-Beckers et al., 2011).

From its establishment during the colonial era in the late eighteenth century to the post-colonial times around the 1960s, Dar es Salaam grew through dictates of planning. Urban open spaces were also provided as the city kept on growing (Brennan and Burton, 2007, Lupala and Bhayo, 2015). It was during the post-colonial era when the city grew informally, that is, in the absence of planning guidelines and standards. This was mainly due to pressure of people migrating from rural to urban areas to seek employment as well as access to health and other services (Wenban-Smith, 2015).

\subsection{Provision of Urban Open Spaces and Intended Use in Dar es Salaam}

Professionals who are key actors in the provision of urban open spaces in Dar es salaam work under policies and legislation of Tanzania, whose routes are traced back from colonial footprint. For example, the Town and Country Planning Ordinance, 1956-Cap 378 was revised in 1961, the year when the country got independence. The Planning Ordinance in section 26 stipulates the provision which may be made in schemes including the reservation of land as open spaces, whether public or private parks, sports grounds and playing fields. The ordinance also provides for the preservation or protection of forests as well as zones or areas in which development of any land shall be restricted or prohibited for general development.

Moreover, in 1993, urban open spaces were provided under the Town and Country Planning (use classes) Regulation, which was an amendment from the Regulation of 1960. Urban open spaces under this regulation are grouped as part of special places of assembly for active recreation referring to sports grounds and playfields as 
well as passive recreation such as private and public gardens, urban squares, incidental open spaces and scenic sites. Other open spaces which are governed by the same regulation include cemeteries and crematoria, campsite and caravan parks, aqua-based recreation sites including swimming pools, sites for boating, rowing, canoeing and beaches.

The National Human Settlements Development Policy of 2000 addresses the role of urban open spaces to be "essential for clean air circulation and breaking up of the monotony of the built-up environment. They are important as children playgrounds and football grounds for recreational purposes. When planted with trees and flowers, open spaces provide greenery and increase the aesthetics of urban areas". The policy emphasizes that open spaces are used for their intended purposes and are protected from being encroached.

Moreover, the National Environmental Management Policy of 2000 instructs how the landscape of urban open spaces and other urban areas used for public use should be improved by emphasizing planting of pollution tolerant species, shade giving and fruits bearing trees as well as ornament trees.

Existing urban open spaces in Dar es salaam result from Master Plans which have been made under the aforementioned guidelines. The detail on how such urban open spaces should be is stipulated in Planning Space Standards for recreational spaces as shown in Table 1. According to the Dar es Salaam Master Plan of 2012-2032, 1.8 percent of land use is for recreational spaces (Note 1) in the city (DMP, 2012).

Table 1. Planning space standards for recreational spaces

\begin{tabular}{lllll}
\hline Type of Facility & Planning level & Population/Unit & $\begin{array}{l}\text { Gross area per } \\
\text { Person }(\mathrm{m} 2)\end{array}$ & $\begin{array}{l}\text { Plot size } \\
(\mathrm{m} 2)\end{array}$ \\
\hline Open space & Neighborhood & $100-150$ & $5.0-10.0$ & $500-1500$ \\
Neighborhood park & Neighborhood & $3000-5000$ & $2.0-5.0$ & $0.6-2.5$ \\
Recreational park & Community & $10,000-20,000$ & $1.5-2.5$ & $1.5-4.0$ \\
Stadium & District/ Town & $100,000-120,000$ & $1.5-2.0$ & $15.0-24.0$ \\
Park & District/ Town & $100,000-120,000$ & $1.0-2.0$ & $10.0-24.0$ \\
\hline
\end{tabular}

Source: URT 1999

For the purpose of exploring sense of place, the study was conducted in two urban open spaces; Magomeni square originally planned as a botanical garden and Mwembeyanga square, which is connected to a park. In this paper the former is abbreviated as M1 and the later M2. The two were selected purposefully for two reasons. First, they are located close to residential settlements and open to the public. Second the planned settlements in which the spaces are located are surrounded by unplanned informal settlements which are characterized by densification of buildings. The presumption is that the squares will be overcrowded by people from the informal settlements around since they are probably the only open public spaces they might need for recreation and other uses. The two squares were selected as instrumental cases for other urban open spaces in the city.

The study adopted qualitative inquiry. Observations and interviews were the main methods for empirical investigation. Observations were meant to explore physical condition of the squares (accessibility, supporting facilities such as benches, bins, and toilet; landscape features such as vegetation, water features) and type of activities that occupy the squares. Two groups of people were interviewed; first, those who were in squares and second, the residents living in settlements close to the squares. The aim of interviews was to get the residents' views on the presence and the significance of squares within their settlements in their everyday activities. Respondents were selected based on a purposive sample of gender and age, and asked about perceptions on the presence of squares to their settlements and their engagement in the squares. In-depth interviews were carried out to 22 people in both M1 and M2 (eight users of the spaces and fourteen residents living in settlements around the urban open spaces). Number of respondents was not pre-selected but it was attained upon noticing the saturation of responses.

\subsection{Situating Magomeni Urban Open Space [M1]}

The urban open space is located about 3 kilometers from Dar es Salaam City center covering an area of about two hectares. It is owned by Kinondoni Municipality since 1960. The square was built in place purposely to serve as a botanical garden and allow people to access nature as well as pursuit of recreation and social activities. There is a 
primary road on its western part, the unpaved street road to the eastern, and northern sides, which border with a densely residential settlement. In the southern part, it was bordered with a church, but recently its land has been grabbed by a new office building making the size of the square smaller about half of its original size.
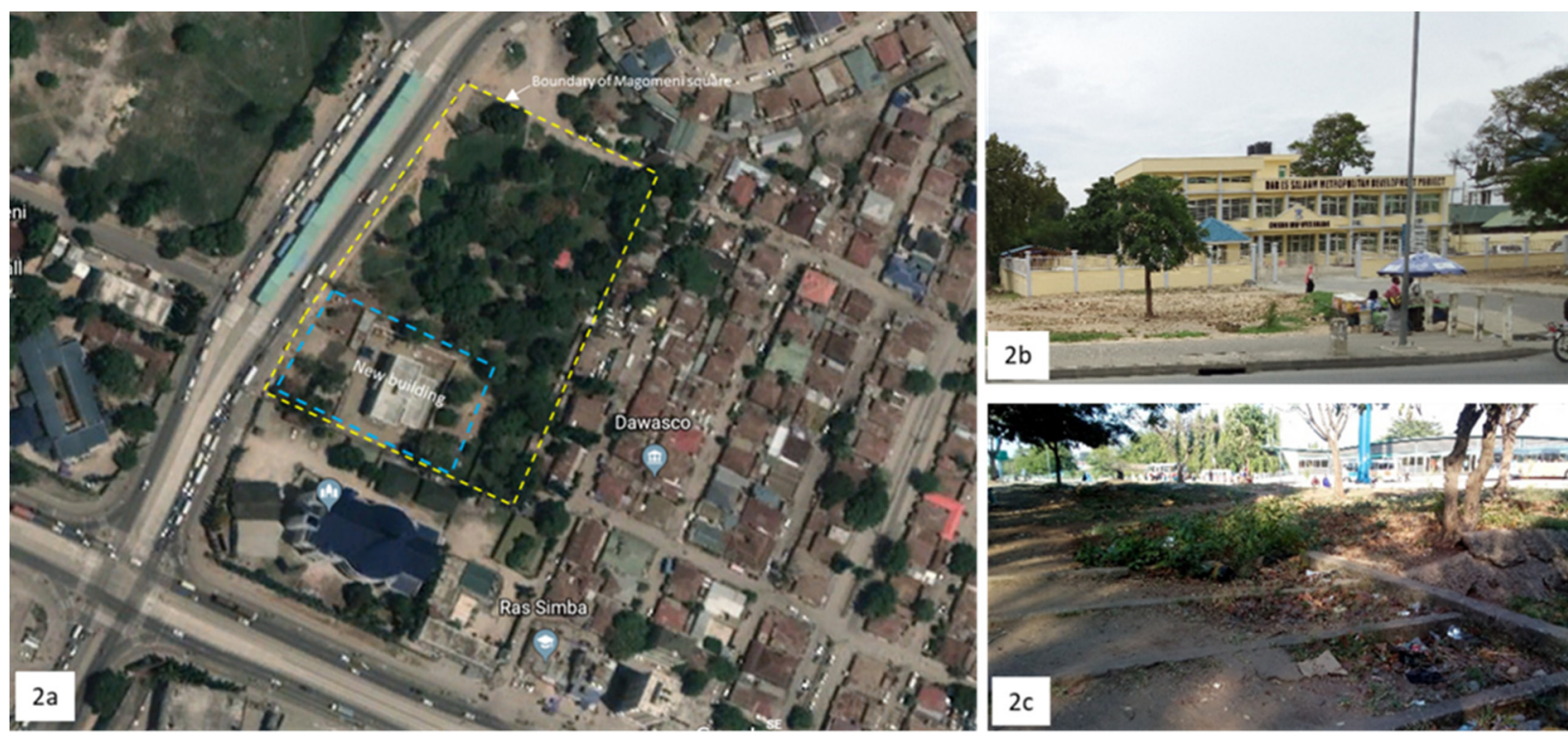

Figure 2. a) Location of Magomeni square [M1], 2b New building constructed in part of the square and 2c View of the square from Eastern part

Source: Fieldwork 2017 and Google earth

\subsection{Situating Mwembeyanga Urban Open Space [M2]}

This is another prominent urban open space situated about five kilometers south east from the Dar es Salaam City centre. Owned by Temeke Municipality, the space was built purposely as a green area in the middle of residential neighbourhoods for access to nature as well as recreational activities. It is surrounded by tarmac roads in its three sides and one unpaved road to the southwest, making it easily accessible.
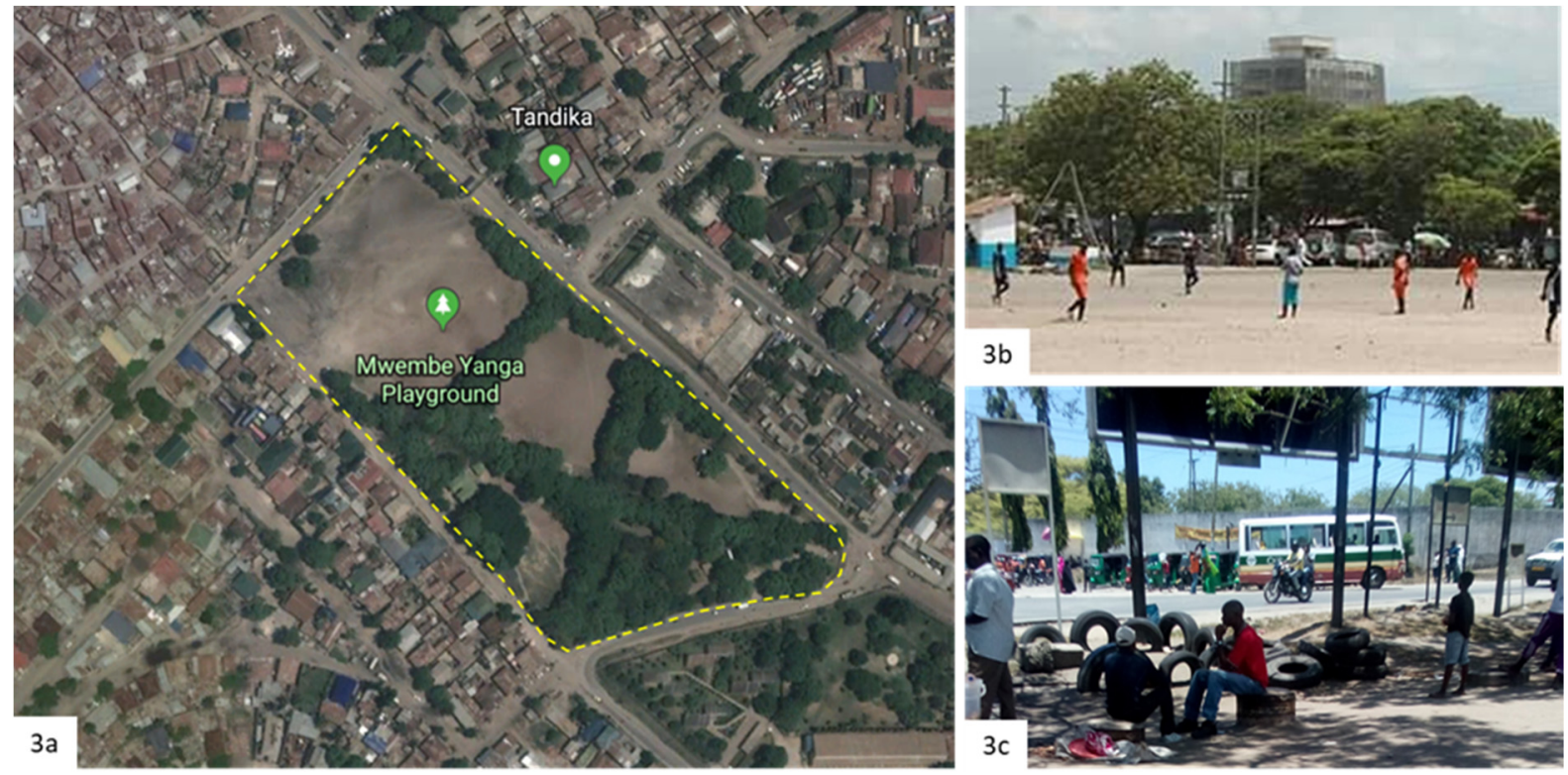

Figure 3. a Location of Mwembeyanga square [M2] 3b Active recreation within the square $3 c$ The edge of the square

Source: Source: Fieldwork 2017 and Google earth 


\section{Results}

Results from the empirical investigation are based on three thematic areas namely; physical qualities of the squares, type of activities and perceptions on space appropriation retrieved from both users and residents living in settlements surrounding the squares.

\subsection{Physical Qualities of the Squares}

The squares are located in strategic positions, which make them visible, but also surrounded by roads for easy accessibility. This supports the notion that physical attributes of a successful urban open space can be tangible, measurable or quantifiable with attributes such as location, accessibility, linkage, size, shape, natural features and so forth (Cilliers and Timmermans, 2016, PPS, 2015b, Shaftoe, 2008). Moreover, both squares have pedestrian cross routes that appeared informally as people move from one side of settlements to another as illustrated in Figure $4 \mathrm{a}$ and $4 \mathrm{~b}$. With respect to supporting facilities, it was found that both squares were well furnished by the time they were built with facilities such as benches, bins, toilets and other attracting features, However, during the time the study was conducted it was observed that some of the facilities have deteriorated. There are remnants of fountains, a pond, swings and concrete benches in M1 squares while in M2 square there is a toilet which is still operational. Although the facilities are in deteriorated condition and others are not found, the few remaining facilities are still essential for attraction of people to the spaces. Both squares have trees along the perimeters and largely covered with unmoored lawn. M2 is surrounded by alleys lined with a row of trees on each side divided into two portions by a row of trees. The alignment of the trees brings a sense of boulevard scenery in the square. M1 brings a bucolic scenery to people around and in it. The abundancy of plants in the two squares does not only serve for aesthetic benefits but also for regulating temperatures and making the spaces more comfortable. Dar es Salaam is located in the tropical climatic region, with warm temperatures and high humidity almost throughout the year. Thus, tree canopies are essential for shades and making outdoor spaces cool. Furthermore, lawn increase comfortability in the place by absorbing hostile solar heat that could be reflective if the surface were covered with a hard surface such as concrete paving blocks. Plants are claimed as one of the attractive features in urban open spaces (Kellert, 1995, Van den Bosch and Bird, 2018). The two squares fairly represent qualities for a successful urban open space. In general, a list of supporting facilities and landscape features is shown in Table 1.

Table 1. Physical condition and landscape features observed from case study

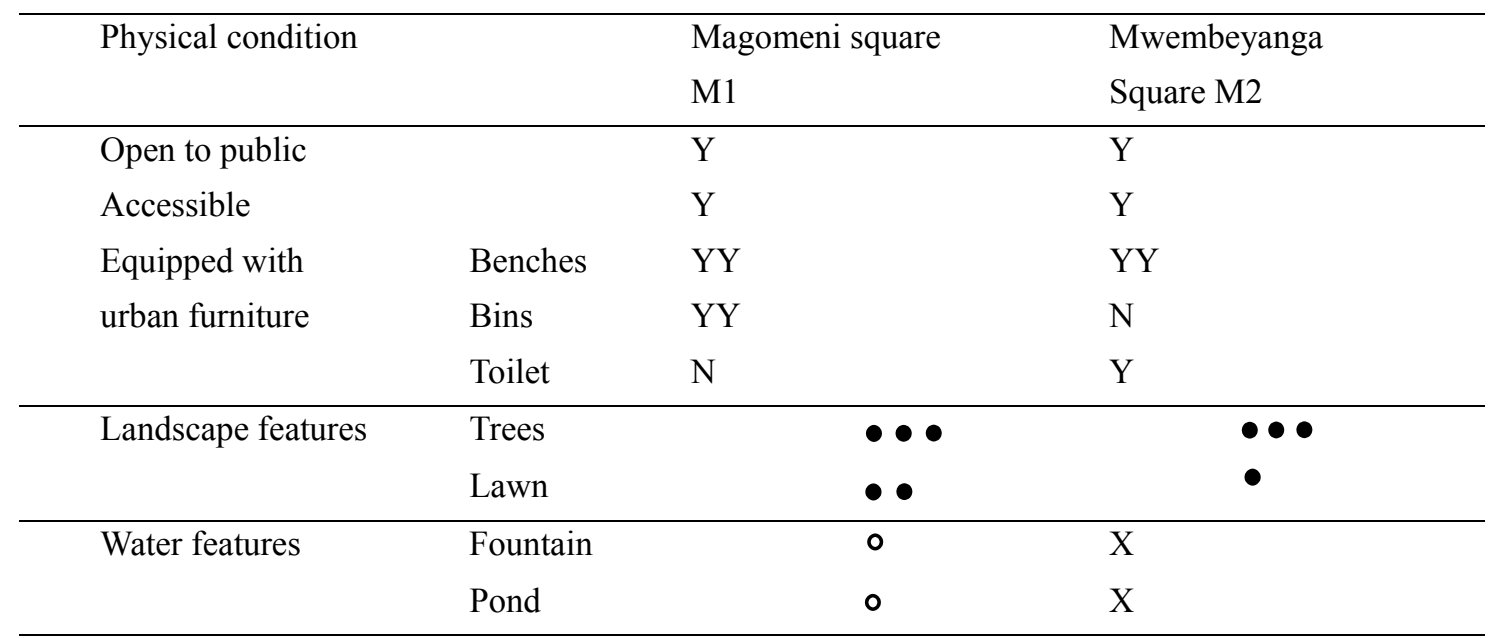

*Key for physical condition

Y $\quad-$ Yes

$Y Y-$ Yes but deteriorated / stolen

$N \quad-N o$
Landscape features

$\begin{array}{ll}\bullet \bullet \bullet & \text { High } \\ \bullet \bullet & \text { Medium } \\ \bullet & \text { Low } \\ \bullet & \text { None }\end{array}$



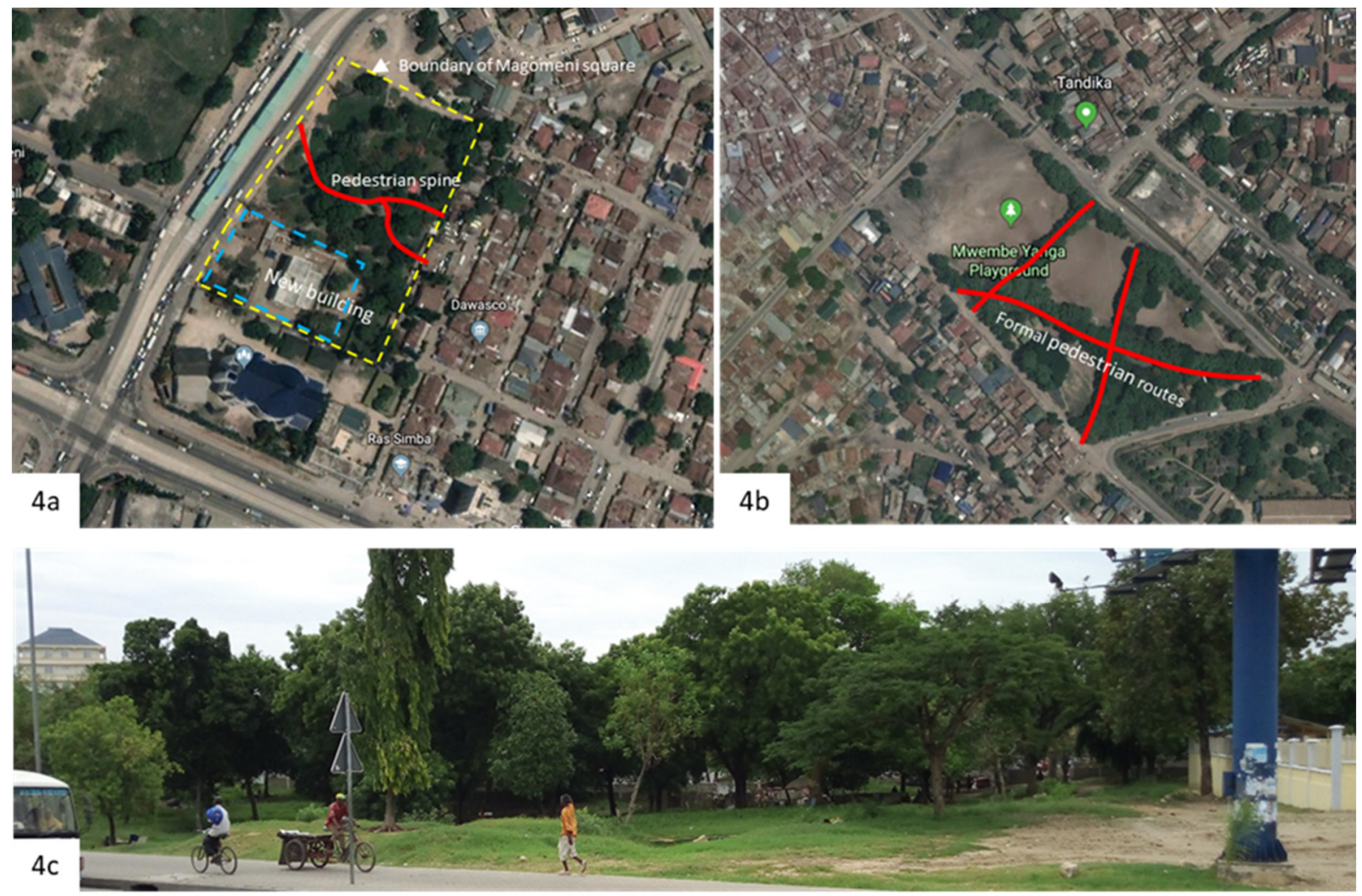

Figure 4. a \& 4b Roads and pedestrian routes for physical permeability in [M1] \& [M2] respectively; Figure 4c Abundancy of trees and lawn in [M1]

Source: Fieldwork 2017

\subsection{Activities Performed in M1 and M2 Squares}

According to observations conducted in two weeks during morning hours, afternoon hours and evening hours in both squares, it was divulged that the squares are dominated with myriad activities including small-scale vending, accommodation for the homelessness as well as lingering of hawkers and young drug addicts. The squares' edges are territorialised by small scale vendors. In M2, vendors are oriented towards the perimeter roads in order to attract customers. In M1, the same situation was observed although vendors were fewer than those in M2. However, some vendors in M1 were in the middle of the square taking advantage of people passing-by on a pedestrian spiral route, which was introduced informally by passers-by as a shortcut. Most of the vendors were young men and women. Notwithstanding the evidence from small scale vendors in the squares, commercial activities in the square are sternly prohibited by the Local Government Authorities.

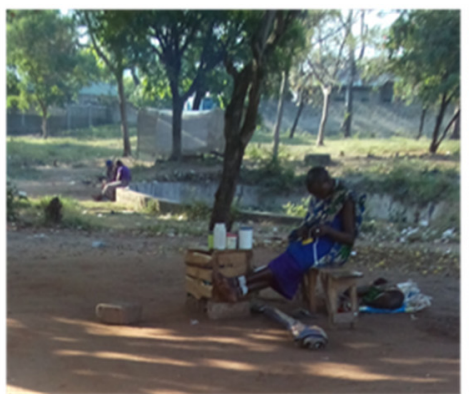

Vending in the middle of M1

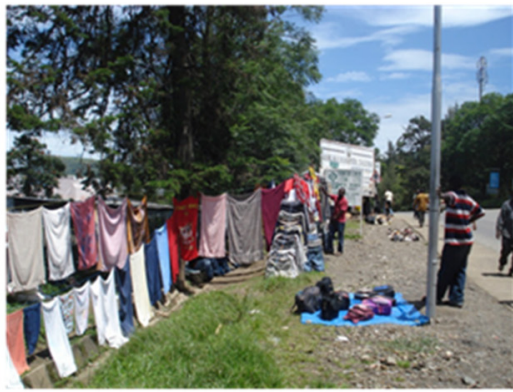

Vending at the edge of M2

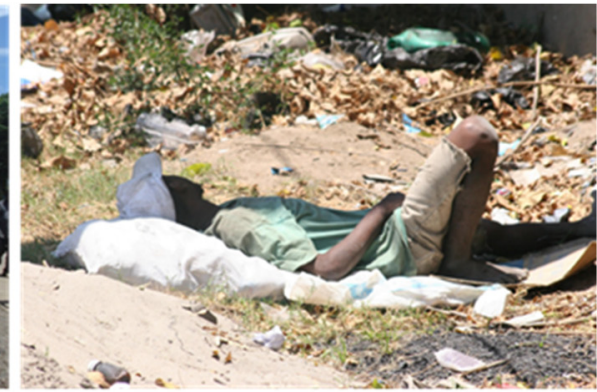

Drug user linger at the edge of Ml

Figure 5. Different activities in urban open spaces

Source: Author; field observation (2017) 
During the evening hours both squares are occupied by children and youths for active recreational activities mainly football as shown in Table 2. In M2, occasional activities such as political and gospel crusades, bonanzas and parades occupy the space. In M1, no occasional activities; instead the area is intruded by shoddily constructed hut that serves as a residential house. According to one of the respondents who was in the house, the owner of the house has been living in the square for the past 16 years and decided to build a hut at the corner while knowing it is illegal to encroach the area. The observed encroachment of the square connotes inadequate management of the squares by the Local Government Authorities concerned.

Table 2. Summary of activities vs time observed in M1 and M2 squares

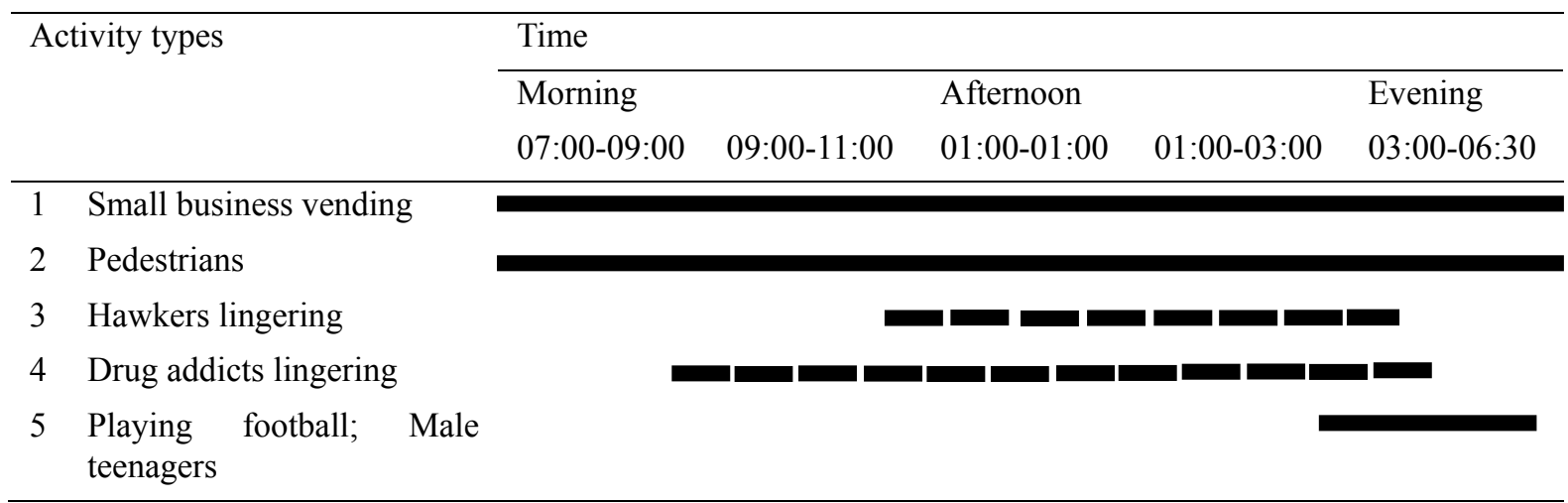

\subsection{Perceptions from Users Found in Squares}

According to feedback from users found in the two squares, the squares are perceived as 'places for vending', 'hiding places' [Mingle to hide] and 'relief points'.

Small scale commercial vendors declare the two squares as their places where they do business and earn income to run their families. They know it is not allowed to run business without permission in the squares but they have been there for many years. One of the respondents at M1 claimed:

"In previous years before the fifth government, we were very much disturbed by city militia but in the current regime (Note 2) we are allowed to carry out small businesses in streets including streets along Magomeni square (M1)".

On the perspective that squares are 'hiding places', one of the homeless persons who is also a drug addict said;

"Magomeni square is our meeting area and hideout for drug taking. Moreover, we wander, linger, converse and sleep in the square. It is a safe place as it is used by a variety of people and thus it is difficult to recognize who is a drug addict".

Contrary to the foregoing, the squares are not occupied by many people other than themselves (drug addicts), a few petty traders and children in the evenings. Also on the perspective that the squares are 'relief points', it was witnessed by hawkers who claimed that they use the squares for resting after walking miles in the city. One respondent asserted,

"I am self-employed as a hawker walking in the streets every day in a week. This space and other urban open spaces are important because I used to rest after a long walk, and also to plan where to go next, to continue doing business. I meet other hawkers in this place. I come here not only for relaxation but also for pausing to breathe before continuing with the business".

Although the aforementioned perceptions entail sense of place contrary to intended use of planners and architects, there were other minor perceptions to which actual use correlated with intended use. This was observed in small groups of teenagers playing football in M2 who expounded that, when they play football in the squares, they feel like they are in the National Stadium. The foregoing statement connotes that the square is a special place for the teenagers from which they get a sense of belongingness and satisfaction in using it.

\subsection{Perceptions from Residents Inhabiting in Settlements around Urban Open Spaces}

According to the interviews conducted with residents in the settlements surrounding the squares, lack of diversity, limited features within the spaces and feeling of insecurity are key aspects that bring about negative perceptions of the squares and, therefore, disassociate with the spaces. 


\subsubsection{Lack of Diversity}

The majority of respondents reported that they are not committed to use the squares, which are close to their settlements. They claimed that it is not their culture to go out to squares and gardens for the sake of engagement with nature as they prefer to engage in spaces, which are associated with richness of activities. They argued that within the settlements there are other small spots which are robust and atractive due to a variety of activities. One of the respondents said;

"I wake up early in the morning to avoid traffic jam on my way to work. In evening hours, I spend most of the time on the road to get back home and, therefore, I better linger at the street corner where I meet friends and share ideas, talking about politics and sports. If I go to the square I will miss my friends".

This narration reveals the lack of diversity of activities in the squares which are preferential to inhabitants.

\subsubsection{Limited Features}

The perception of limited features in the squares was reported as among the factors, which make the spaces less preferred for recreational and leisure uses. Although the squares are close to residential settlements, they seem to have limited features apart from trees and urban furniture that would otherwise attract more diverse population.

Many individuals prefer going out to beaches during weekends and festivals. They argue that beaches are better places because they meet many people even if they don't know each other. At the beach, people enjoy interacting with water and sand rather that trees available in the square. One respondent at M2 said;

"This square is a place for teenagers. I used to play here years ago when I was in primary school but now, my family and I go to the beach during weekends. The city has a lot of good beaches. It is where people from all over the city go during weekends to breeze. Therefore, this square will remain a place for teenagers to play".

This narration illuminates water feature as an important element for making spaces attractive. However, the absence of water feature in the squares, lead to the sense of placelessness of the spaces among the Dar es Salaam City residents.

\subsubsection{Feeling of Insecurity}

The feeling of insecurity was reported as being one of the obstacles for efficient use of the squares. One of the respondents said:

"The squares are not good places because of the presence of drug addicts who calmly sleep in the square and although not disturbing anyone, the feeling of lack of safety simmers involuntarily”.

Another respondent in a neighbourhood overlooking M1 added:

"I cannot take my children to relax in the square although it is closer to my house, because you never know about 'mateja' [drug addicts] who linger in the area. They are dangerous sometimes, especially when they need money to buy drugs. We have often heard robbery cases among our colleagues coming from the bus stop to the settlement via the pedestrian route'.

The sense of security can be referred to the writings of Jane Jacobs with the concept of 'the eye on the street' who postulates that streets are busy, occupied by pedestrians and watched by people in adjacent buildings, their eyes provide informal surveillance to the environment (Jacobs, 1961, Fuller and Moore, 2017). This connotation is similar to the squares in which the sense of security is attained in the presence of many people. However, the sense of insecurity which is found in the squares is mainly due to lack of large number of people in the spaces.

Regarding visual attraction of the squares, respondents reported that the squares are visually attractive due to the richness of plants for a variety of purposes like shade, colours, form and alignment of paths. However, the residents are rather attracted by everyday social and leisure activities happening in spaces within settlements which are not available in the squares. They argued that they have their own ways of attaining happiness, which do not necessarily need someone to go out to squares.

\section{Discussion}

The results obtained from empirical investigation from the two squares reveal that sense of place is not a generalized concept as far as urban open spaces are concerned. A sense of place is attained when a space comprises optimal physical attributes such as accessibility and linkage that provide good connection with surrounding environment (PPS, 2015b, Marcus and Francis, 1998); or rich in landscape features such as trees and plants (Kellert, 1995). It is also argued that a place makes sense when it is rich in urban features such as sitting, fixed and moveable spaces, water features, food concessions as well as activities and relationship of spaces (Whyte, 1980). However, 
in some contexts, these features are not enough to make sense of place as revealed in the observed squares. The squares are redefined with activities which are contrary to the intended activities. The dominance of commercial related activities in the urban open spaces that were planned purposely for recreational activities portrays another understanding of urban open spaces in the context of Dar es salaam. Also, meanings people give to the urban open spaces show that the spaces are not for intended functions that relate to recreation and social interaction as per planners' imaginations. Unlike meanings such as 'hiding places', which bring negative connotation to the urban open spaces, meanings such as 'relief point' and 'place for vending' signify commercial value of the spaces. While the 'relief point' is interrelated more into the aspects of physical attribute of the spaces, it also portrays commercial values of hawkers to whom the urban open spaces are prominent. Meanings associated with 'places for vending' signify that urban open spaces in the context of Dar es Salaam are beyond traditional intended meanings.

\section{Conclusion}

Generally, planning and design of urban open spaces in cities are adapted from ideas of Ebenezer Howard and Patrick Geddes who pioneered the provision of urban open spaces to cities for recreational benefits (Pretty et al., 2007). Their ideas were adapted and purveyed across many parts of the globe, and the sense of place reflecting planning intentions is revealed in the actual uses of the spaces in cities of global North. Findings from the two squares in Dar es salaam reveal other aspects of sense of place beyond the intended. The study has established that urban open spaces are sensed in varied dimensions including vending, relief points and hiding places. This paper recommends that planning and design of urban open spaces ought to be contextual based.

\section{Acknowledgments}

We acknowledge the financial support from SIDA as well as the leadership and people of Magomeni and Mwembeyanga where the study took place.

\section{References}

Adinolfi, C., Suárez-Cáceres, G. P., \& Carinanos, P. (2014). Relation between visitors' behaviour and characteristics of green spaces in the city of Granada, south-eastern Spain. Urban Forestry \& Urban Greening, 13(3), 534-542. https://doi.org/10.1016/j.ufug.2014.03.007

Andreasen, M. H. (2013). Population Growth and Spatial Expansion of Dar es Salaam: An analysis of the rate and spatial distribution of recent population growth in Dar es SalaamEn analyse af vækstraten og den rumlige fordeling af nylig befolkningstilvækst i Dar es Salaam.

Augustijn-Beckers, E.-W., Flacke, J., \& Retsios, B. (2011). Simulating informal settlement growth in Dar es Salaam, Tanzania: An agent-based housing model. Computers, Environment and Urban Systems, 35(2), $93-$ 103. https://doi.org/10.1016/j.compenvurbsys.2011.01.001

Behera, A. (2017). Reimagining Contemporary Urban Planning with Placemaking.

Bishop, K., \& Marshall, N. (2017). Social Interactions and the Quality of Urban Public Space. https://doi.org/10.1016/B978-0-12-409548-9.10177-0

Bleam, R. M. (2018). Unbounded place meanings and embodied place identities for conservation volunteers in Scottsdale, Arizona. Journal of environmental psychology. https://doi.org/10.1016/j.jenvp.2018.03.002

Brennan, J., \& Burton, A. (2007). The emerging metropolis: a short history of Dar es Salaam, circa 1862-2005.

Burrows, E., O’Mahony, M., \& Geraghty, D. (2018). How Urban Parks Offer Opportunities for Physical Activity in Dublin, Ireland. International journal of environmental research and public health, 15(4), 815. https://doi.org/10.3390/ijerph15040815

Carmona, M. (2010). Public places, urban spaces: the dimensions of urban design. Routledge.

Chapin, F. S., \& Knapp, C. N. (2015). Sense of place: A process for identifying and negotiating potentially contested visions of sustainability. Environmental Science \& Policy, 53, 38-46. https://doi.org/10.1016/j.envsci.2015.04.012

Cilliers, E. J., \& Timmermans, W. (2016). Transforming spaces into lively public open places: case studies of practical interventions. Journal of Urban Design, 21(6). https://doi.org/10.1080/13574809.2016.1234336

Dadvand, P., Bartoll, X., Basagaña, X., Dalmau-Bueno, A., Martinez, D., Ambros, A., ... Borrell, C. (2016). Green spaces and general health: roles of mental health status, social support, and physical activity. Environment International, 91, 161-167. https://doi.org/10.1016/j.envint.2016.02.029

DMP. (2012). Dar es salaam masterplan 2012-2032, Main report, first draft December 2012. 
Fan, P., Xu, L., Yue, W., \& Chen, J. (2017). Accessibility of public urban green space in an urban periphery: The case of Shanghai. Landscape and urban planning, 165, 177-192. https://doi.org/10.1016/j.landurbplan.2016.11.007

Francis, M. (2003). Urban open space: Designing for user needs. Island Press.

Freestone, R., \& Liu, E. (2016). Place and placelessness revisited. Routledge. https://doi.org/10.4324/9781315676456

Fuller, M., \& Moore, R. (2017). The death and life of great American cities. Macat Library.

Giuliani, M. V. (2003). Theory of attachment and place attachment. na.

Gkoutis, G. (2014). The Social Construction of Place Meaning: Exploring Multiple Meanings of Place as an Outdoor Teaching and Learning Environment. In.

Gozalo, G. R., Morillas, J. M. B., González, D. M., \& Moraga, P. A. (2018). Relationships among satisfaction, noise perception, and use of urban green spaces. Science of The Total Environment, 624, 438-450. https://doi.org/10.1016/j.scitotenv.2017.12.148

Jackson, J. B. (1994). A sense of place, a sense of time. Yale University Press. https://doi.org/10.2307/4091350

Jacobs, J. (1961). The death and life of American cities.

Jennings, V., Larson, L., \& Yun, J. (2016). Advancing sustainability through urban green space: cultural ecosystem services, equity, and social determinants of health. International journal of environmental research and public health, 13(2), 196. https://doi.org/10.3390/ijerph13020196

Johnson, A. J., \& Glover, T. D. (2013). Understanding urban public space in a leisure context. Leisure Sciences, 35(2), 190-197. https://doi.org/10.1080/01490400.2013.761922

Jorgensen, B. S., \& Stedman, R. C. (2001). Sense of place as an attitude: Lakeshore owners attitudes toward their properties. Journal of environmental psychology, 21(3), 233-248. https://doi.org/10.1006/jevp.2001.0226

Kabisch, N., \& Haase, D. (2014). Green justice or just green? Provision of urban green spaces in Berlin, Germany. Landscape and urban planning, 122, 129-139. https://doi.org/10.1016/j.landurbplan.2013.11.016

Kellert, S. R. (1995). The biophilia hypothesis. Island Press.

Kiunsi, R. B. (2013). A review of traffic congestion in Dar es Salaam city from the physical planning perspective. Journal of Sustainable Development, 6(2), 94. https://doi.org/10.5539/jsd.v6n2p94

Kyle, G., \& Chick, G. (2007). The social construction of a sense of place. Leisure Sciences, 29(3), 209-225. https://doi.org/10.1080/01490400701257922

Low, S. (2017). Spatializing culture: The ethnography of space and place. Taylor \& Francis. https://doi.org/10.4324/9781315671277

Lupala, J., \& Bhayo, S. A. (2015). Building Densification as a Strategy for Urban Spatial Sustainability: Analysis of Inner City Neighbourhoods of Dar Es Salaam, Tanzania. Global Journal of Human-Social Science Research.

Manzo, L. C., \& Devine-Wright, P. (2013). Place attachment: Advances in theory, methods and applications. Routledge. https://doi.org/10.4324/9780203757765

Marcus, C. C., \& Francis, C. (1998). People places: design guidlines for urban open space. John Wiley \& Sons.

McCunn, L. J., \& Gifford, R. (2014). Interrelations between sense of place, organizational commitment, and green neighborhoods. Cities, 41, 20-29. https://doi.org/10.1016/j.cities.2014.04.008

McCunn, L. J., \& Gifford, R. (2017). Spatial navigation and place imageability in sense of place. Cities. https://doi.org/10.1016/j.cities.2017.12.006

Misra, S., \& Stokols, D. (2012). A typology of people-environment relationships in the Digital Age. Technology in society, 34(4), 311-325. https://doi.org/10.1016/j.techsoc.2012.10.003

Musa, H. D., Yacob, M. R., Abdullah, A. M., \& Ishak, M. Y. (2018). Enhancing subjective well-being through strategic urban planning: Development and application of community happiness index. Sustainable cities and society, 38, 184-194. https://doi.org/10.1016/j.scs.2017.12.030

NBS. (2013). National Bureau of statistics, Tanzania population and housing census 2012-Population distribution by administrative areas. Ministry of Finance. 
Norberg-Schulz, C. (1980). Genius loci: Towards a phenomenology of architecture. Rizzoli.

Paris, M. (2017). Making Prestigious Places: How Luxury Influences the Transformation of Cities. Routledge. https://doi.org/10.4324/9781315312453

PPS. (2015a). PPS-Project for public spaces. Retrieved July 17, 2018, from https://www.pps.org/article/grplacefeat

PPS. (2015b). Projects for public spaces. Retrieved July 17, 2018, from htpp://www.pps.org/about/

Pretty, J., Ball, A., Benton, T., Guivant, J., Lee, D. R., Orr, D., Pfeffer, M., \& Ward, H. (2007). The SAGE handbook of environment and society. Sage.

Rådsten Ekman, M. (2015). Unwanted Wanted Sounds: Perception of sounds from water structures in urban soundscapes. Department of Psychology, Stockholm University.

Relph, E. (1976). Place and placelessness (Vol. 1). Pion.

Salama, A., \& Azzali, S. (2015). Examining attributes of urban open spaces in Doha. Proceedings of the ICEUrban Design and Planning, 168(2), 75-87. https://doi.org/10.1680/udap.14.00011

San Juan, C., Subiza-Pérez, M., \& Vozmediano, L. (2017). Restoration and the city: the role of public urban squares. Frontiers in psychology, 8, 2093. https://doi.org/10.3389/fpsyg.2017.02093

Schindler, M., Le Texier, M., \& Caruso, G. (2018). Spatial sorting, attitudes and the use of green space in Brussels. Urban Forestry \& Urban Greening, 31, 169-184. https://doi.org/10.1016/j.ufug.2018.02.009

Shaftoe, H. (2008). Convivial urban spaces: Creating effective public places. Earthscan.

Steele, F. (1981). The sense of place. Cbi Pub Co.

Tan, S.-K., Tan, S.-H., Kok, Y.-S., \& Choon, S.-W. (2018). Sense of place and sustainability of intangible cultural heritage-The case of George Town and Melaka. Tourism Management, 67, 376-387. https://doi.org/10.1016/j.tourman.2018.02.012

Teimouri, R., Ghorbani, R., \& Hojjati, H. (2017). Investigation of the Relationship between Public Green Space and Urban Life Quality. Environmental Management and Sustainable Development, 6(1), 28-39. https://doi.org/10.5296/emsd.v6i1.10467

Thomas, D. (2016). Placemaking: An urban design methodology. Routledge. https://doi.org/10.4324/9781315648125

Tuan, Y.-F. (1990). Topophilia: A study of environmental perceptions, attitudes, and values. Columbia University Press.

UN. (2016). The world'd cities in 2016.

UN-Habitat. (2014). World urbanisation prospects-United Nations. Retrieved from Retrieved April 26, 2018, from https://esa.un.org/unpd/wup/publications/files/wup2014-highlights.pdf

UNHabitat. (2015). Habitat III issue papers 11-Public spaces.

URT. (2012). Dar es salaam master plan 2012-2032.

URT. (2013). (Goverment of Tanzania 2013), 2012 Population and housing census: Population distribution by administrative areas. Dar es salaam, Tanzania national bureau of statistics.

Van Den Bosch, M., \& Bird, W. (2018). Oxford textbook of nature and public health: The role of nature in improving the health of a population. Oxford University Press. https://doi.org/10.1093/med/9780198725916.001.0001

Waller, T., Ärlemalm-Hagsér, E., Sandseter, E. B. H., Lee-Hammond, L., Lekies, K., \& Wyver, S. (2017). The SAGE handbook of outdoor play and learning. Sage. https://doi.org/10.4135/9781526402028

Webber. (1974). Permissive planning,'In the future of cities'. London: Hutchinson educational.

Wenban-Smith, H. (2015). Population growth, internal migration and urbanisation in Tanzania, 1967-2012. London, UK: International Growth Centre.

Whyte, W. H. (1980). The social life of small urban spaces.

Zhou, X., \& Parves Rana, M. (2012). Social benefits of urban green space: A conceptual framework of valuation and accessibility measurements. Management of Environmental Quality: An International Journal, 23(2), 173-189. https://doi.org/10.1108/14777831211204921 


\section{Notes}

Note 1. Recreation spaces are classified as Open spaces, public parks, play grounds, botanical gardens, golf courses, forests and beaches DMP 2012. Dar es salaam Master Plan 2012-2032, Main report, first draft December 2012.

Note 2. The current regime (2015-2020) refers to the government headed by His Exellency President John Pombe Magufuli.

\section{Copyrights}

Copyright for this article is retained by the author(s), with first publication rights granted to the journal.

This is an open-access article distributed under the terms and conditions of the Creative Commons Attribution license (http://creativecommons.org/licenses/by/4.0/). 